\title{
PEACE THROUGH LAW: THE ROLE AND LIMITS OF ADJUDICATION*
}

\section{CLARENCE MORRIS $\dagger$}

"The power of the judge," says Ehrlich, "is not sufficient to overcome the enormous powers of resistance inherent in society which would rise up in opposition to an attempt to place society on a new foundation by means of a judicial pronouncement . . . . The judge has often, it is true, disregarded the law in the service of an unscrupulous sovereign power; occasionally, supported by the law, he has been able to offer successful resistance to a strong sovereign power; but he has never risked a conbat [sic] with the state, society, and traditional law." 1 Ehrlich's point is that courts come into being, not as policydirecting organs of the state capable of initiating and organizing new forms of social movement, but rather as organs of society whose novel contributions can, at most, articulate social trends already widely ingrained in society. To be more concrete, courts cannot initiate, for example, a system of collective farming, or a scheme of international disarmament inspection; they have, on the other hand, been able to adopt equitable defenses, recognize and define the right to privacy, and reformulate the laws of spite fences-without legislative action and without involving themselves in enforcement crises.

The judicial need for social roots explains, in part, the insistence that courts write opinions disclosing the grounds on which their decisions rest. A court seems to act "legitimately" (and I use this word advisedly) only when its premises command social support. It legitimates its decisions by announcing those premises. Cardozo talks of this when he says that retrospective judicial lawmaking would be intolerable if community ideas of social justice were not usually the source of judicial doctrines. ${ }^{2}$

There are great areas, then, in which no one would suppose judicial action appropriate. What is not so clear is that judicial substantive justice plays no part in many cases which courts dispose of on their

* An address delivered to the Annual Meeting of the American Society for International Law, April 23, 1960, at Washington, D.C.

† Professor of Law, University of Pennsylvania. LL.B. 1925, University of Colorado; LL.M. 1926, Columbia University.

1 Eerlich, Fundamental Principles of the Soctology of Law 181 (Moll trans. 1936).

2 Cardozo, The Nature-of the Judicial Process 142 (1921). 
merits. We labor under the delusion that courts decide all disputes which they try on the merits. Courts do, of course, dispose of all these disputes, but disposition and decision are not the same thing.

The point I am trying to make is this. When a court does not know what to do, it usually tries to do nothing-it holds that the complainant has failed to establish a "legal" right. This, of course, is what the court should do, for any other holding would be meddlesome or random activity. However, not all inaction results from indecision. Sometimes a court is convinced that a complainant deserves no relief. For example, a holding in a slander suit that truth is a defense is not a decision that the defamed merely has failed to persuade the court that he has a right; it is a firm decision that his claim lacks merit.

This distinction bears on the "rationality" of judicial decision. A judicial decision can be rational only when supported by acceptable substantive grounds-positive or negative. A judicial decision is prerational when a court does not know what to do, and therefore does nothing. I do not, of course, say irrational. A judge unable to choose between competing theories of litigants is no more irrational than a physicist unable to choose between the competing theories of the nature of light. The difference is that the judge, unlike the scientist, cannot willingly suspend judgment: litigation must end quickly; scientific ignorance can persist until substantive discovery is made.

Unfortunately, a pre-rational judicial decision has forensic status as a precedent and spawns a rule for refusing to act in other similar cases. This is not entirely a mistake of logic-making something out of nothing. If judges are to respect the justice of the rule requiring equal protection of the law, defendants answering to similar complaints must be treated similarly. Of course, judicially announced law can be changed-a court whose reason for change is not based on the identity of litigants is no undue respecter of persons. But a new holding may require stronger conviction when it overrules an old one than when it pronounces judgment unembarrassed by precedent. I am not naive about the ability of lawyers to differentiate the indistinguishable, and neither are judges who use this ability. (Parenthetically, we can remark the wisdom of the system that permits a top appellate court to refuse to hear a case that it is unready to decide. This is no panacea; it can result in a failure to give attention to problems ripe for substantive judicial judgment.)

Rationality of decision, as distinguished from what I have called pre-rationality, is demonstrated only when the court "speaks justice"a metaphor by which I am trying to convey a philosophic, moral, psy- 
chological, and social meaning. Satisfying judicial rationality is a work of art, in a sense. Though I am by no means his disciple, let me quote Ehrlich again. "[T]hough justice is based on social trends," he says, "it requires the personal activity of an individual to make it effective. In this it is most like art. The artist, too, as we know today, does not produce his work of art from his inner self; he can but give shape to that which society furnishes him with. . . . [J] ustice owes to society only its rough content, but owes its individual form to the artist in justice who has created it." 3

Pushing on from Ehrlich's analogy, note these two points: first, art, judicial or aesthetic, is unlikely to satisfy those who must live with it unless it seems to be the right answer to the problem faced. Esoteric solutions are accepted only from those whose stature guarantees their wisdom and even these tall ones must look to their laurels when the critics are skeptical of their answers. So excellence in works of art or law is social in effect as well as in cause; the artist gets his materials from society and completes his mission only when he returns to society a product that will be accepted as right. Second, artists and jurists have roles, recognized by themselves as well as by society. These roles channel their behavior and set its conceivable limits. "We must keep within those interstitial limits," says Cardozo, "which precedent and custom and the long and silent and almost indefinable practice of other judges through the centuries of the common law have set to judge-made innovations." 4

Legislators are permitted more leeway in experiment than judges. "There are," says Traynor, "no adequate precedents for much of the law that must be formulated today to regulate multiminded, multihanded human beings. The main preoccupation of such law must be with the future. Its main formulation," he continues, "belongs appropriately to legislators, who are freer than judges to write on a clean slate, in terms of policy transcending case or controversy, and to erase and rewrite in response to community needs." 5 While the opponents of a bill in Congress may attack it as a dangerous experiment, yet Congress did not step out of its role when, for example, it first adopted the municipal bankruptcy law for a three-year period. ${ }^{6}$ Imagine, however, how Blackburn, J., would have sounded had he said in Rylands

3 EHRLICH, op. cit. supra note 1, at 208.

4 Cardozo, op. cit. supra note 2, at 103.

5 Traynor, Comment on Courts and Lazmaking, in Legal Institutions Today AND TOMORRow 48, 50 (Paulsen ed. 1959).

${ }^{6}$ Act of Aug. 16, 1937, ch. 657, §84, 50 Stat. 653. 
v. Fletcher: ${ }^{7}$ "For the next three years, an impounder of a substance likely to do damage if it escapes, acts at his peril." I do not mean courts never retreat from their mistakes; they have recently done so, for example, in the law of prenatal injuries. 8 I do not mean decrees in particular cases may not be revised; they often are in injunction and nonsupport cases. I do mean that the formal principle announced by a court making a new law must be treated as though it were enduring, and it will, therefore, tend to endure. A Cardozo must be willing to rule, in effect, that, from the MacPherson case ${ }^{9}$ on, manufacturers owe consumers a duty to use care for their safety.

So I doubt Cardozo himself when, imbued with modern pragmatism, he says, "not all the progeny of principles begotten of a [judicial] judgment survive . . . to maturity. Those that cannot prove their worth and strength by the test of experience are sacrificed. . . ." We are not realistic if we put great faith in this hope for judicial activism. I agree, rather, with Traynor when he says:

There is now wide agreement that a judge can and should participate creatively in the development of the common law. Yet each time he does so, he must reckon with the ancient suspicion that creativeness is a disturbing excess of skill, at odds with circumspection, darkly menacing the stability of the law. . .

The real concern is not the remote possibility of too many creative opinions but their continuing scarcity. The growth of the law . . . is . . . hampered by a judicial lethargy that masks itself as judicial dignity . . . .11

Bentham, referring to the shock of judicial novelty, says "nor is the mischief cured till a strong body of connected decisions either in confirmation of the first anomalous one or in opposition to it have repaired the broken thread of analogy . . . ."12 The judge who readapts the law disturbs tradition in vain and denies even-handed justice to the parties before him, unless he acts with the conviction that justice will settle in the new channel which he opens. In a court staffed with heterogeneous judges, the problem of inventive, creative decision (as opposed to pre-rational inertia) is more difficult. Learned Hand, writing more than forty years ago, said:

T L.R. 1 Ex. 265 (1866), aff'd, L.R. 3 H.L. 330 (1868).

8 See, e.g., Woods v. Lancet, 303 N.Y. 349, 102 N.E.2d 691 (1951).

${ }^{9}$ MacPherson v. Buick Motor Co., 217 N.Y. 382, 111 N.E. 1050 (1916). In this case the court held that negligent manufacturers imperiling consumers life and limb could no longer escape liability on the ground that they were not in privity of contract with consumers injured because of their negligence.

10 Cardozo, op. cit. supra note 2, at 22.

11 Traynor, supra note 5 , at 52.

12 Bentham, The Limits of Jurisprudence Defined 281 (Everett ed. 1945). 
Until within a very few decades the . . . bench and bar could utter justice without misgiving or constraint. . . . The selfconscious elements of society were homogeneous and the divergences not fundamentally distracting. . . . All this is changed . . . [Other classes'] demands are vocal which before were dumb . . . . If justice be a passable accommodation between the vital and seif-conscious interests of society, it has taken on a meaning not known before. ${ }^{13}$

If Hand is right, our widened American spectrum of values greatly taxes judicial lawmaking. How much more difficult will be the task of judges in an international tribunal to know their own minds and to know, in addition, that they must persuade not only their colleagues but also those who follow after if their court is to establish a rule of substantive law rather than a series of conflicting decisions or an ongoing practice of doing nothing.

This Comment is about both the role of, and the limits on, adjudication. Most of my words have been negative-about what courts cannot or will not do. But the affirmative role of adjudication has indeed been impressive in the past. In England, the King's courts, inventing and applying their own law, were able to advance the King's peace over the conflicts of manors and baronies-each with its own law. I heard Thurman Arnold say years ago, "Who could have predicted the public utility holding company at the time of the Civil War?" Who, indeed, at the time of Westminster II could have predicted how the "consimili casu" clause was to extend the function of common-law courts from trespass, to case, to assumpsit; and how the remedies for checking the feudal foray were to expand into the whole common law of torts and contracts? So, too, the adjudicative process may indeed serve the cause of world peace. My fear is that we hope for too much too soon in this direction. "The success of the law as a unifying force," says Thurman Arnold, "depends on making emotionally significant the idea of a government of law which is rational and scientific." 14 An international adjudicative process can play some part in unifying nations, but other forces are indeed needed for a rational and scientific international polity.

13 Hand, The Speech of Justice, 29 Harv. L. REv. 617, 619 (1916).

14 Arnold, The Symbols of Government 49 (1935). 